\title{
Assessment of Genetic Diversity in Summer Squash Genotypes Using some Yield Traits and DNA Markers Analysis under Sinai Conditions
}

\author{
Mohamed A. Abdein ${ }^{1}$, Ahmed B. El-Mansy ${ }^{2}$, Nabil S. Awad ${ }^{3,4}$ and Diaa Abd El-Moneim ${ }^{5 *}$ \\ ${ }^{1}$ Biology Department, Faculty of Arts and Science, Northern Border University, Rafha, Kingdom of Saudi Arabia. \\ ${ }^{2}$ Department of Plant Production, (Vegetables Branch), Faculty of Environmental Agricultural Sciences, Arish \\ University, El-Arish, 45511 Egypt \\ ${ }^{3}$ Department of Genetics, Faculty of Agriculture and Natural Resources, Aswan University, Aswan, Egypt \\ ${ }^{4}$ College of Biotechnology, Misr University for Science and Technology, Giza, Egypt \\ ${ }^{5}$ Department of Plant Production, (Genetic Branch), Faculty of Environmental Agricultural Sciences, Arish University, \\ El- Arish, 45511 Egypt
}

\section{Received: 4/2/2021}

\begin{abstract}
Fourteen summer squash genotypes were used to assess their genetic diversity and relationships using some yield traits (Fruit length, fruit diameter, fruit shape index, average fruit weight, No of fruits/plant, fruit yield, and total soluble solids \%) and DNA markers (Random Amplified Polymorphic DNA, inter-simple sequence repeat, Start Codon Targeted polymorphism) analyses. Two open field trials were executed at two locations, i.e., El-Arish $\left(\mathrm{L}_{1}\right)$ and Ras Sidr $\left(\mathrm{L}_{2}\right)$ in the North and South Sinai-Egypt, respectively. Significant differences were observed between both locations and indicated the superiority of $\left(\mathrm{L}_{1}\right)$ than $\left(\mathrm{L}_{2}\right)$ in all studied traits, while the interaction between genotype and location was significant for all studied traits. The location had a major effect on the relative genotypic potential of these traits, in which the genotype $\times$ location interaction was highly significant. SQ6 genotype ranked as the first in the fruit yield/plant and SQ2 for fruit diameter followed by SQ7 and SQ2 for fruit shape as well as SQ13 and SQ12 for the number of fruits/plant in $\mathrm{L}_{1}$ and $\mathrm{L}_{2}$ locations, respectively. Additionally, high polymorphism percentage (P \%) was detected using RAPD (85\%), ISSR (79.25\%) and SCoT (69.44). Among the 15 studied primers, OP-B17 showed the maximum P\% (100\%) followed by primer OP-C17 (90.9\%) which also scored the highest values for polymorphism information content, effective multiplex ratio, and marker index. In addition, OP-K01 represented the maximum value of resolving power (12.56), indicated that these primers were highly informative. Intriguingly, 55 positive and two unique negative bands were amplified, out of which (33) bands were generated by RAPD followed by SCoT (15) and ISSR (9). In this regard, OP-C17 and SQ1 genotype produced the highest number of unique marker18 and 11 amplicon, respectively. Moreover, the maximum similarity was found between SQ 11 and SQ 12 indicating that both genotypes were the most similar. Cluster and PCA analysis using RAPD, ISSR, and SCoT data grouped the 14 squash genotypes into four, three and two distinct clusters, respectively. Generally, the yield traits alongside molecular results showed significant information that may be utilized to sort and relationship between the studied summer squash genotypes under different conditions.
\end{abstract}

Keywords: Squash (Cucurbita pepo), Genetic diversity, Yield traits, RAPD, ISSR, SCoT, Sinai

\section{INTRODUCTION}

Summer squash (Cucurbita pepo L.) is one of the paramount vegetable crops of Cucurbitaceae family cultivated throughout the world. It is a cross pollinated plant, and its diploid chromosomal number is $(2 \mathrm{n}=40)$. Its origin is Northern Mexico (Tropical America) and is amongst the most ancient cultivated crops in the America (Paris, 1996). Production of squash \& pumpkins in Asia comprises half or more of the total area devoted to pumpkins and squash worldwide (Albrifcany, 2015). Squash is cultivated all over the year in Egypt, in the open field during spring and summer, where in tunnels or greenhouses in fall and winter (Abd-Alrahman et al., 2020). According to Egyptian Ministry of Agriculture and Land Reclamation, the total production area of squash in 2016 was 73558 fed and produced 551023 tons of fruits (Nassar et al., 2019). At the same time, it is considered an important source of human food, many nutrients, and medicinal uses (Matlob et al., 1989; Abd El-Hadi et al., 2017). The low production of summer squash in some production regions due to the deficiency in fruit setting resulted from unfavorable sex expression and bad crosspollination flowers due to short blooming period (Albrifcany, 2015). Therefore, these restrictions need further studies including the environmental factors and cultural practices to increase crop production with desired quality (Mohammed, 1996). Genotype selection is also a key management component in plant breeding program in order to improve production quality characteristics. Several previous studies i.e., Ferreira et al. (2003), Al-Araby (2004), Abdein (2005), Al-Araby (2010), Fayeun et al. (2012) Tamil et al. (2012), Abd El-Hadi et al. (2014) were interested in investigating the genetics performance under different conditions. When cultivars are grown in different locations, their performance was observed to vary according to environmental variations of these locations. This variation may refer to changes in environmental conditions such as temperature, soil type, moisture and so on (Robertson, 1959). Inconsistent genotypic responses to environmental factors from location to location, is a function of $\mathrm{G} \times \mathrm{E}$ interaction, hence resulting in alteration to the ordering of genotypes from one environment to another. Lately, plant breeders utilized modern methods such as molecular marker to evaluate genetic variability (Abd El-Hadi et al., 2017). DNA fingerprinting is an indispensable tool towards tracing of lineages in plant lines. Unlike the morphological and biochemical markers that could be 
much influenced with environmental factor and growth practices, DNA markers could portray genomic sequences composition thus enabling to detect genetic differences carried by different individuals (Xiao et al., 1996; Ovesna et al., 2002). Three of such useful markers system have been employed: (i) Random Amplified Polymorphic DNA (RAPD) uses an arbitrary, short primer that anneals to the genome at complementary sequences, and sizes of amplified products reveal existing polymorphisms (Nadeem et al., 2018) and have been applied successfully in diversity analyses of C. pepo (Athanasios et al., 2009; Ntuli et al., 2013; Mady et al., 2013; Someh et al., 2016), (ii) ISSR markers (Zietkiewicz et al., 1994) are based on the amplification of DNA regions located between two microsatellites loci and used successfully in diversity analyses of C. pepo (Katzir et al., 2000; Heikal et al., 2008; Inan et al., 2012; Kiani and Siahchehreh, 2017) and (iii) Start Codon Targeted polymorphism (SCoT) is a gene targeted molecular marker technique derived from flanking ATG translation codon in plant gene and is considered to be more authentic in assessing genetic homogeneity (Xiong et al., 2011; Abdein et al., 2018). SCoT analysis has been also used to study genetic relationships in C. pepo (Xanthopoulou et al., 2015; Bhawna et al., 2017). SCoT technique can be used as an effective complementary method to ISSR and RAPD (Abd El-Moneim, 2019). In the same context, different investigations studied the genetic diversity and relationships belonging to Cucurbita by comparing their molecular markers (SRAP and RAPD) (Ferriol et al., 2003); ISSR, SRAP \& RAPD (Yildiz et al., 2011); ISSR \& SRAP (Inan et al., 2012); ISSR \& SSR (Yildiz et al., 2014) and SCoT \& ISSR (Abdein, 2018). Phenotypic evaluation in Cucurbita has traditionally been based on seed and fruit characteristics. These have proved useful in distinguishing samples of related species but exhibit inadequate variation for intraspecific discrimination of cultivars and involves a limited number of phenotypic characters effected by environmental influences (Dijkhuizen et al., 1996). In this regard, phenotypic markers in Cucurbita have been found to be unreliable and with no molecular basis (Wilson, 1989). Molecular information provides deeper insight into genetic structure, while detection of heterozygous loci utilizing marker techniques would give more realistic genetic relationships. Additionally, molecular evaluation was more favorable than phenotypic evaluation because it had more markers and represented neutral traits of simple inheritance (Sensoy et al., 2007; Athanasios et al., 2009). Some differences were observed between molecular and morphological studies, and it was concluded that only morphological or molecular analyses but a combination of both approaches are often more reliable in genetic variability studies in Cucurbita genus (Inan et al., 2012). Therefore, the main objective of this work is to estimate diversity analysis of 14 genotypes of Cucurbita pepo based on variation in some yield traits attributes along with molecular markers revealed by RAPD, ISSR and SCoT markers. Finally, to provide recommendation for utilization of the important landraces in a breeding program to increase genetic diversity and to develop useful inbred lines of C. pepo.

\section{MATERIALS AND METHODS}

\section{Field experiment:}

Two open field trials were conducted in two different locations in Sinai Peninsula. Both locations have a desert climate (BWh) according to the KöppenGeiger climate classification. $1^{\text {st }}$ location (El-Arish) at the Research Farm of Fac. Environ. Agric. Sci., Arish Uni., Egypt that located at, $31^{\circ} 07^{\prime} 34.0^{\prime \prime} \mathrm{N} / 33^{\circ} 49^{\prime} 31.4^{\prime \prime} \mathrm{E}$. while, $2^{\text {nd }}$ location (Ras Sidr) in South Sinai, Egypt and located at $29^{\circ} 37^{\prime} 32.5^{\prime \prime} \mathrm{N} / 32^{\circ} 42^{\prime} 48.6^{\prime \prime} \mathrm{E}$. The mechanical and chemical analyses of the experimental soil and irrigation water (average of two seasons) are presented in (Tables 1 and 2); their analysis was done according to the methods described by Piper (1947) and Jackson (1958).

Table (1): Initial physical and chemical properties of the experimental soil for two locations

\begin{tabular}{|c|c|c|c|}
\hline \multirow{2}{*}{ Parameter } & & \multicolumn{2}{|c|}{ Soil depth 0-35 (cm) } \\
\hline & & El-Arish $\left(\mathbf{L}_{1}\right)$ & $\operatorname{Ras} \operatorname{Sidr}\left(\mathbf{L}_{2}\right)$ \\
\hline \multicolumn{4}{|c|}{ Physical analysis } \\
\hline Sand (\%) & & 89.39 & 80.6 \\
\hline Silt (\%) & & 4.51 & 8.61 \\
\hline Clay $(\%)$ & & 6.10 & 10.79 \\
\hline Soil texture & & Loamy sand & Loamy sand \\
\hline \multicolumn{4}{|c|}{ Chemical analysis } \\
\hline \multirow{4}{*}{ Cations (meq. $1^{-1}$ ) } & $\mathrm{Ca}^{++}$ & 6.72 & 12.3 \\
\hline & $\mathbf{M g}^{++}$ & 5.10 & 8.7 \\
\hline & $\mathrm{Na}^{+}$ & 12.67 & 24.2 \\
\hline & $\mathbf{K}^{+}$ & 0.40 & 0.8 \\
\hline \multirow{4}{*}{ Anions (meq. $\left.1^{-1}\right)$} & $\mathrm{CO}_{3}^{--}$ & - & - \\
\hline & $\mathrm{HCO}_{3}^{-}$ & 2.45 & 3.00 \\
\hline & $\mathrm{CI}^{-}$ & 14.41 & 30.50 \\
\hline & $\mathrm{SO}_{4}^{--}$ & 8.03 & 13.00 \\
\hline E.C $\left(d S . m^{-1}\right)$ & & 2.489 & 4.65 \\
\hline pH & & 7.9 & 7.7 \\
\hline
\end{tabular}

According to (Jackson, 1958) 
Table (2): Initial chemical analyses of irrigation water for two locations

\begin{tabular}{|c|c|c|}
\hline Parameter & El-Arish $\left(\mathrm{L}_{1}\right)$ & $\operatorname{Ras} \operatorname{Sidr}\left(\mathrm{L}_{2}\right)$ \\
\hline E.C $\left(d S . m^{-1}\right)$ & 3.22 & 7.85 \\
\hline Concentration (ppm) & 2048 & 5024 \\
\hline pH & 7.5 & 7.77 \\
\hline \multicolumn{3}{|c|}{ Soluble cations $\left(\right.$ meq. $\mathrm{l}^{-1}$ ) } \\
\hline $\mathrm{Ca}^{++}$ & 8.64 & 20.50 \\
\hline $\mathbf{M g}^{++}$ & 6.03 & 8.60 \\
\hline $\mathrm{Na}^{+}$ & 17.05 & 48.89 \\
\hline $\mathbf{K}^{+}$ & 0.50 & 0.35 \\
\hline \multicolumn{3}{|c|}{ Soluble anions (meq.. ${ }^{-1}$ ) } \\
\hline $\mathrm{CO}_{3}^{--}$ & - & - \\
\hline $\mathrm{HCO}_{3}^{-}$ & 4.62 & 5.00 \\
\hline $\mathrm{Cl}^{-}$ & 22.26 & 57.50 \\
\hline $\mathrm{SO}_{4}^{--}$ & 5.34 & 16.20 \\
\hline
\end{tabular}

According to (Jackson, 1958)

\section{Plant materials and growth conditions:}

Fourteen imported genotypes of summer squash (Cucurbita pepo) were evaluated for yield and some attributed traits during the 2017 and 2018 summer seasons under open field conditions in El-Arish, and Ras Sidr, Sinai, Egypt. The genotypes used in this study are presented in (Table 3). Average temperatures prevailing at $\left(\mathrm{L}_{1}\right)$ and $\left(\mathrm{L}_{2}\right)$ locations are given in (Fig. 1). Seeds were directly planted in the open field on the $3^{\text {rd }}$ week of March in both locations. Two to four seeds were sown around emitters of dripper lines in a randomized complete block design (RCBD) with three replicates. The experimental unit was two ridges $5.0 \mathrm{~m}$. long and $1.2 \mathrm{~m}$. wide. Plants were set $50 \mathrm{~cm}$ apart in the bed and were subjected to common agricultural practices. After two weeks of sowing, plants were thinned to one plant. Thus, each plot contained 20 plants; fruits were harvested at a marketable stage at 50 days after planting and transferred to the laboratory. Eight fruits were randomly assigned from each plot to determine the following traits: 1) fruit length (FL, cm), 2) fruit diameter $(\mathrm{FD}, \mathrm{cm}), 3)$ fruit shape index $(\mathrm{FShI})$, 4) average fruit weight (WF, gm), 5) number of fruits per plant (NoFP), 6) fruit yield (FY, kg/plant) and 7) total soluble solids percentage (TSS\%, measured by Brix refractometer).

Table (3): Genotypes code, origin and names of 14 squash genotypes

\begin{tabular}{|c|c|c|c|}
\hline \multicolumn{2}{|c|}{ Genotypes } & \multirow{2}{*}{ Origin } & \multirow{2}{*}{ Name } \\
\hline Number & Code & & \\
\hline 1 & SQ1 & EGYPT & ESKANDARANI \\
\hline 2 & SQ2 & FRANCE & WHITE BUSH SCALLOP \\
\hline 3 & SQ3 & USA & ZUCCHINE KRITI \\
\hline 4 & SQ4 & TURKI & SIYAH KABUK \\
\hline 5 & SQ5 & IRAQ & FIVE STAR \\
\hline 6 & SQ6 & TURKI & KABAK DOLMALIK KOLSUZ \\
\hline 7 & SQ7 & IRAQ & ERBIL GARDEN \\
\hline 8 & SQ8 & GERMANY & ZUCCHINI DIAMANT \\
\hline 9 & SQ9 & SYRIA & HALAB \\
\hline 10 & SQ 10 & TURKI & BEYAZ SAKIZ KABAK \\
\hline 11 & SQ11 & ITALY & ZUCCHINO ALBERALLO DI SARZANA \\
\hline 12 & SQ12 & TURKI & SAKIZ KABGI \\
\hline 13 & SQ13 & USA & ALEXANDIA \\
\hline 14 & SQ14 & ITALY & ZUCCHINO BIANCO DI TRIESTE \\
\hline
\end{tabular}




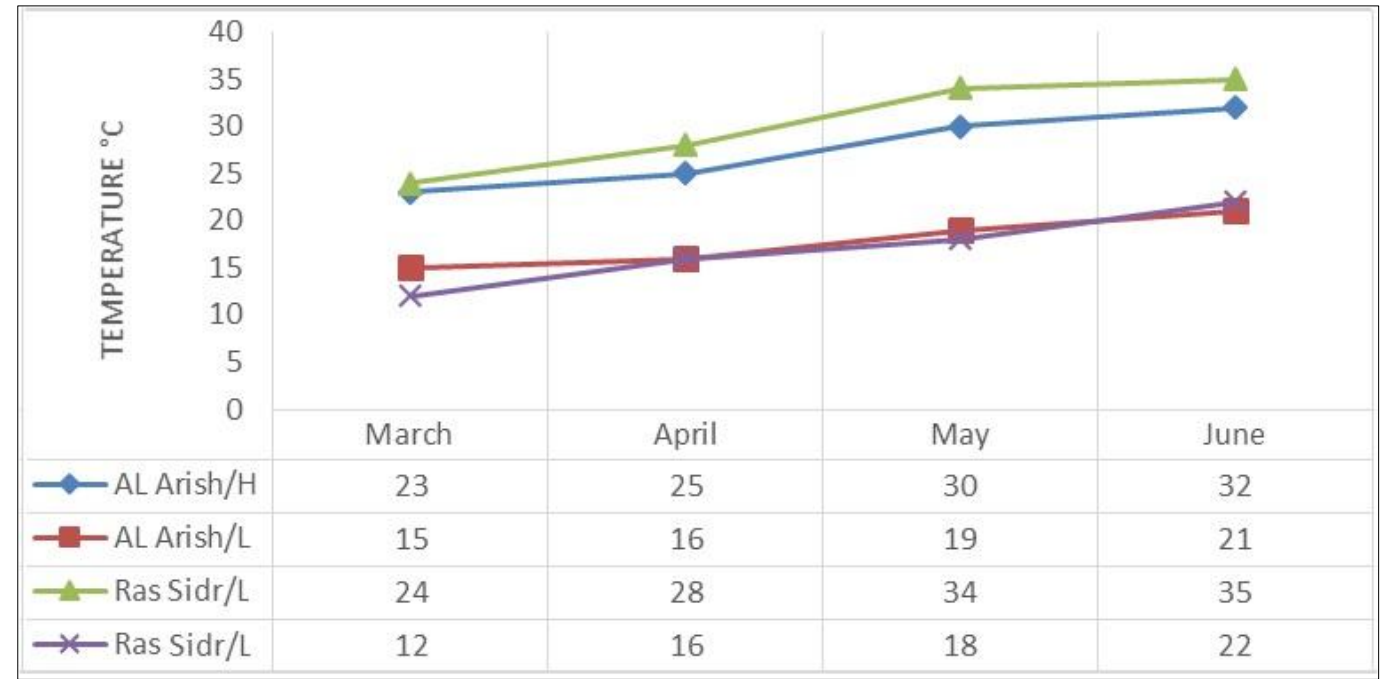

Figure (1): Average of high and low temperatures prevailing at $\left(\mathrm{L}_{1}\right)$ and $\left(\mathrm{L}_{2}\right)$ locations

\section{Statistical analysis:}

Data collected were analyzed using ASSISTAT Version 7.7 en, UFCG-Brazil (Silva and Azevedo, 2016a,b) computer program package. The data were first subjected to analysis of variance for each location using the procedure illustrated by Gomez and Gomez (1984) for a randomized complete block design over both years. A combined analysis of variance was computed using the same software (ASSISTAT) to study the genotype $\times$ location interaction. Phenotypic $(\mathrm{PCV} \%)$ and genotypic (GCV\%). Coefficient of variability was calculated according to Singh and
Chaudhury (1985). Heritability based on (Stansfield, 1983).

Molecular Marker analysis:

Genomic DNA extraction and PCR procedures:

The total genomic DNA was extracted from young leaf pieces using a DNA Plant Kit (Qiagen) USA. Five primers/markers (Table 4) were screened for the studied genotypes. RAPD, ISSR, and SCoT markers amplification were performed as described by (Hussein et al., 2006) and (Collard and Mackill, 2009), respectively. PCR products were visualized by conventional agarose gel electrophoresis.

Table (4): List of the primers names and their nucleotide sequences used in the study for RAPD, ISSR, and SCoT procedure

\begin{tabular}{|c|c|c|c|}
\hline Name & RAPD Sequence $(5 \rightarrow \mathbf{3})$ & Name & ISSR Sequence $(\mathbf{5} \rightarrow \mathbf{3})$ \\
\hline OP-A9 & GGGTAACGCC & 44B & СТC ТCT СТС ТСТ СТC TAG \\
\hline OP-B17 & CTCACCGTCC & 49A & СТСТСТСТСТСТСТСТТG \\
\hline OP-C13 & GGACCCAACC & HB-8 & GAGAGAGAGAGAGG \\
\hline OP-C17 & AAG CCT CGT G & HB-11 & GTGTGTGTGTGTTGTCC \\
\hline \multirow[t]{2}{*}{ OP-K1 } & TGC CGA GCT G & HB-13 & GAGGAGGAGC \\
\hline & SCoT Sequence $(\mathbf{5} \rightarrow \mathbf{3})$ & & \\
\hline SCoT 1 & ACGACATGGCGACCACGC & & \\
\hline SCoT 2 & ACCATGGCTACCACCGGC & & \\
\hline SCoT 3 & ACGACATGGCGACCCACA & & \\
\hline SCoT 4 & ACCATGGCTACCACCGCA & & \\
\hline SCoT 6 & CAA TGG CTA CCA CTA CAG & & \\
\hline
\end{tabular}

DNA banding pattern analysis:

The DNA banding patterns generated from ISSR and SCoT markers were analysed by Gel works ID advanced software. The presence or absence of each recorded band for each genotype is indicated by (1) or (0). Genetic similarity was calculated by Jaccard's coefficient. A dendrogram was generated with the unweighted pair group method with arithmetic mean (UPGMA) algorithm using the computational package
MVSP V. 3.1. To assess the informativeness of the markers, the following parameters were calculated for each primer according to (Anderson et al., 1993; Powell et al., 1996; Prevost and Wilkinson, 1999): polymorphism information content (PIC), effective multiplex ratio (EMR), marker index (MI) and resolving power (Rp). The principal coordinate analysis PCA (Davis, 1986) was used to find the eigen values and eigenvectors of a matrix containing the similarities between all genotypes. 


\section{Yield traits}

\section{RESULTS}

Highly significant differences were observed between the two locations for fruit length, average fruit weight, fruit yield/plant, and TSS \%, while fruit diameter, fruit shape index, and number of fruits/plant exhibited only significant differences between the two locations (Table 5). Data in (Table 6) showed a wide range of variation among the tested genotypes regarding these traits in both locations. The performance values of traits ranged from $4.08 \mathrm{~cm}$ (SQ2) to $14.2 \mathrm{~cm}$ (SQ10) for fruit length, $2.05 \mathrm{~cm}$ (SQ3) to 7.18 (SQ2) for fruit diameter, 0.64 (SQ2) to 4.20 (SQ7) for fruit shape index, $92.750 \mathrm{~g}$ (SQ3) to $221.083 \mathrm{~g}$ (SQ9) for average fruit weight, 15.08 (SQ2) to 30.42 (SQ12) for the number of fruits/plant, $1.655 \mathrm{~kg}$ (SQ4) to $2.769 \mathrm{~kg}$ (SQ6) for fruit yield/plant and 1.85 (SQ4) to $7.20 \%$ (SQ11) for total soluble solids percentage.

Table (5): Mean squares of combined analysis of variance over two locations for yield traits

\begin{tabular}{|c|c|c|c|c|c|c|c|c|}
\hline VS & df & FLcm & FDcm & FShI & WFg & NoFP & FYPkg & TSS $\%$ \\
\hline Location (L) & 1 & $29.39 * *$ & $19.98 *$ & $12.97^{*}$ & $25.47 * *$ & $24.00^{*}$ & $29.32 * *$ & $28.30 * *$ \\
\hline Error-a & 2 & 0.2953 & 0.8041 & 0.3042 & 0.1267 & 1.2232 & 0.2205 & 0.2647 \\
\hline Genotype (G) & 13 & $50.25 * *$ & $14.72 * *$ & $10.70 * *$ & $11897.19 * *$ & $104.62 * *$ & $0.73 * *$ & $18.46^{* *}$ \\
\hline $\mathbf{G} \times \mathbf{L}$ & 13 & $0.174 * *$ & $0.532 *$ & $0.325^{*}$ & $3.655^{* *}$ & $2.968^{*}$ & $0.370 * *$ & $0.600 * *$ \\
\hline Error-b & 52 & 0.018 & 0.2777 & 0.1787 & 1.477 & 1.4828 & 0.1476 & 0.2442 \\
\hline
\end{tabular}

*,** Significant and highly significant at 0.05 and $0.01 \%$ probability levels, respectively

Table (6): Combined means of yield traits as affected by locations (L) and genotypes (G) of squash

\begin{tabular}{|c|c|c|c|c|c|c|c|}
\hline Treatment & FLcm & FDcm & FShI & WFg & NoFP & FYPkg & TSS\% \\
\hline \multicolumn{8}{|c|}{ Location } \\
\hline $\mathbf{L}_{1}$ & 11.02 & 4.76 & 2.75 & 167.952 & 24.05 & 2.830 & 5.04 \\
\hline $\mathbf{L}_{2}$ & 9.83 & 3.79 & 1.97 & 166.851 & 23.05 & 1.649 & 3.88 \\
\hline LSD & 0.51 & 0.84 & 0.52 & 0.335 & 0.81 & 0.441 & 0.92 \\
\hline \multicolumn{8}{|c|}{ Genotypes } \\
\hline$\overline{\text { SQ1 }}$ & 12.35 & 2.55 & 3.60 & 116.75 & 21.92 & 2.145 & 2.75 \\
\hline SQ2 & 4.08 & 7.18 & 0.64 & 129.083 & 15.08 & 1.694 & 5.05 \\
\hline SQ3 & 10.35 & 2.05 & 4.07 & 92.75 & 23.58 & 1.748 & 2.95 \\
\hline SQ4 & 8.05 & 5.95 & 1.06 & 140.75 & 15.58 & 1.655 & 1.85 \\
\hline SQ5 & 8.71 & 5.21 & 1.25 & 197.458 & 24.25 & 2.380 & 5.56 \\
\hline SQ6 & 13.24 & 3.67 & 3.67 & 118.375 & 25.42 & 2.769 & 3.63 \\
\hline SQ7 & 12.90 & 2.38 & 4.20 & 205.458 & 25.58 & 2.173 & 3.10 \\
\hline SQ8 & 9.11 & 4.96 & 1.37 & 212.875 & 26.58 & 2.434 & 6.97 \\
\hline SQ9 & 8.45 & 5.76 & 1.16 & 221.083 & 20.58 & 2.110 & 5.87 \\
\hline SQ 10 & 14.20 & 3.80 & 2.79 & 194.625 & 23.58 & 2.373 & 3.23 \\
\hline SQ11 & 8.20 & 4.98 & 1.17 & 192.167 & 25.42 & 2.560 & 7.20 \\
\hline SQ12 & 13.13 & 2.43 & 4.00 & 121.542 & 30.42 & 2.474 & 3.95 \\
\hline SQ13 & 9.65 & 5.17 & 1.38 & 208.292 & 26.75 & 2.196 & 6.80 \\
\hline SQ14 & 13.52 & 3.75 & 2.67 & 192.417 & 24.92 & 2.644 & 3.58 \\
\hline$\overline{\text { LSD }}$ & 1.06 & 1.07 & 0.86 & 5.615 & 2.47 & 0.683 & 1.00 \\
\hline Mean & 10.4 & 4.3 & 2.4 & 167.4 & 23.5 & 2.2 & 4.5 \\
\hline Minimum & 4.08 & 2.05 & 0.64 & 92.750 & 15.08 & 1.655 & 1.85 \\
\hline Maximum & 14.2 & 7.18 & 4.20 & 221.08 & 30.4 & 2.769 & 7.20 \\
\hline
\end{tabular}

Results obtained from each location (over seasons) as shown in (Tables 7 and 8), indicated It is interested to note that, some genotypes constantly behaved at both locations: i.e., SQ7 and both SQ6 and SQ9 in fruit length and fruit diameter, respectively and most genotypes in both fruit shape and number of fruits/plant as well as all genotypes in average fruit weight (Table
7). Some genotypes fluctuated from one location to another with certain traits, i.e., fruit shape index (Table 7 ), where SQ1 was 4.24 in $1^{\text {st }}$ location while it was 2.97 in the $2^{\text {nd }}$ one. Fruit diameter in the same genotype was $3.13 \mathrm{~cm}$ in the $1^{\text {st }}$ region and $1.97 \mathrm{~cm}$ in the second. Fruit yield (Table 8) for SQ2 was $2.446 \mathrm{~kg}$ in $1^{\text {st }}$ location, while it was $0.943 \mathrm{~kg}$ in the $2^{\text {nd }}$ one. TSS 
percentage in the same genotype was $5.63 \%$ in the $1^{\text {st }}$ region and $4.47 \%$ in the second. The interaction between genotype and location was highly significant for fruit length, average fruit weight, fruit yield/plant and $\mathrm{TSS} \%$, and significant all other studied traits.

The best genotype which ranked the first in the studied traits was genotype SQ2, SQ6, SQ9, SQ10, and SQ11 in both locations for fruit diameter, fruit yield/plant, average fruit weight, fruit length and $\mathrm{TSS} \%$, respectively; SQ7 and SQ2 for fruit shape as well as SQ13 and SQ12 for the number of fruits/plant in 1st and $2^{\text {nd }}$ localities, respectively. The pertinent of variance components in addition to genotypic (GCV) and phenotypic (PCV) coefficients of variability for yield traits are presented in Table (9). Genetic variation $\left(\sigma^{2} g\right)$ was large in magnitude compared to error one $\left(\sigma^{2} \mathrm{e}\right)$ and $\sigma^{2} \mathrm{~g} \times 1$ in all studied traits. Estimates of the genotypic and phenotypic coefficients of variation (Table 8 ) were determined with slight differences between them for all studied traits except WFg in the $1^{\text {st }}$ region and NoFP in both regions. However, heritability in broad sense was high for all traits.

Table (7): Combined means of fruit length, fruit diameter, fruit shape index, and the average fruit weight as affected by the interaction of locations and genotypes of squash

\begin{tabular}{|c|c|c|c|c|c|c|c|c|}
\hline \multirow{2}{*}{ Item } & \multicolumn{2}{|c|}{ FLcm } & \multicolumn{2}{|c|}{ FDcm } & \multicolumn{2}{|c|}{ FShI } & \multicolumn{2}{|c|}{ WFg } \\
\hline & $\mathbf{L}_{1}$ & $\mathbf{L}_{2}$ & $\mathbf{L}_{1}$ & $\mathbf{L}_{2}$ & $\mathbf{L}_{1}$ & $\mathbf{L}_{2}$ & $\mathbf{L}_{1}$ & $\mathbf{L}_{2}$ \\
\hline SQ1 & 12.93 & 11.77 & 3.13 & 1.97 & 4.24 & 2.97 & 117.333 & 116.167 \\
\hline SQ2 & 4.67 & 3.50 & 7.77 & 6.60 & 0.60 & 0.69 & 129.667 & 128.500 \\
\hline SQ3 & 10.93 & 9.77 & 2.63 & 1.47 & 4.15 & 3.99 & 93.333 & 92.167 \\
\hline SQ4 & 8.63 & 7.47 & 6.53 & 5.37 & 1.32 & 0.81 & 141.333 & 140.167 \\
\hline SQ5 & 9.29 & 8.13 & 5.79 & 4.63 & 1.60 & 0.89 & 198.222 & 196.694 \\
\hline SQ6 & 13.83 & 12.65 & 3.26 & 4.09 & 4.25 & 3.08 & 118.778 & 117.972 \\
\hline SQ7 & 13.48 & 13.32 & 2.96 & 1.81 & 4.56 & 3.83 & 206.222 & 204.694 \\
\hline SQ8 & 9.69 & 8.53 & 5.54 & 4.38 & 1.75 & 0.98 & 213.444 & 212.306 \\
\hline SQ9 & 9.02 & 7.87 & 5.89 & 5.64 & 1.53 & 0.78 & 221.556 & 220.611 \\
\hline SQ10 & 14.78 & 13.62 & 4.38 & 3.22 & 3.38 & 2.20 & 195.444 & 193.806 \\
\hline SQ11 & 8.83 & 7.58 & 5.63 & 4.33 & 1.57 & 0.76 & 192.667 & 191.667 \\
\hline SQ12 & 13.73 & 12.53 & 3.07 & 1.79 & 4.52 & 3.47 & 122.667 & 120.417 \\
\hline SQ13 & 10.27 & 9.04 & 5.73 & 4.60 & 1.79 & 0.96 & 208.333 & 208.250 \\
\hline SQ14 & 14.13 & 12.90 & 4.37 & 3.14 & 3.24 & 2.10 & 192.333 & 192.500 \\
\hline LSD & \multicolumn{2}{|c|}{0.86} & \multicolumn{2}{|c|}{0.93} & \multicolumn{2}{|c|}{0.7124} & \multicolumn{2}{|c|}{4.522} \\
\hline
\end{tabular}

Table (8): Combined means of fruits number/plant, fruit yield/plant, and TSS\% as affected by the interaction of locations and genotypes of squash

\begin{tabular}{lcccccc}
\hline & \multicolumn{3}{c}{ NoFP } & \multicolumn{2}{c}{ FYPkg } & \multicolumn{3}{c}{ TSS\% } \\
\hline Item & $\mathbf{L}_{\mathbf{1}}$ & $\mathbf{L}_{\mathbf{2}}$ & $\mathbf{L}_{\mathbf{1}}$ & $\mathbf{L}_{\mathbf{2}}$ & $\mathbf{L}_{\mathbf{1}}$ & $\mathbf{L}_{\mathbf{2}}$ \\
\hline SQ1 & 22.67 & 21.17 & 2.729 & 1.562 & 3.33 & 2.17 \\
SQ2 & 15.33 & 14.83 & 2.446 & 0.943 & 5.63 & 4.47 \\
SQ3 & 24.33 & 22.83 & 2.331 & 1.164 & 3.53 & 2.37 \\
SQ4 & 16.00 & 15.17 & 2.236 & 1.074 & 2.43 & 1.27 \\
SQ5 & 24.67 & 23.83 & 2.962 & 1.798 & 6.14 & 4.98 \\
SQ6 & 24.67 & 26.17 & 3.347 & 2.191 & 4.21 & 3.04 \\
SQ7 & 26.33 & 24.83 & 2.746 & 1.600 & 3.68 & 2.52 \\
SQ8 & 26.33 & 26.83 & 2.971 & 1.898 & 7.56 & 6.39 \\
SQ9 & 20.67 & 20.50 & 2.689 & 1.531 & 6.46 & 5.29 \\
SQ10 & 24.00 & 23.17 & 3.131 & 1.614 & 3.81 & 2.64 \\
SQ11 & 26.67 & 24.17 & 3.005 & 2.115 & 7.77 & 6.64 \\
SQ12 & 30.67 & 30.17 & 3.045 & 1.903 & 4.53 & 3.38 \\
SQ13 & 27.67 & 25.83 & 2.772 & 1.620 & 7.37 & 6.24 \\
SQ14 & 26.67 & 23.17 & 3.216 & 2.071 & 4.17 & 2.99 \\
\hline LSD & & $\mathbf{2 . 1 2}$ & & $\mathbf{0 . 6 4 2 2}$ & & \\
\hline
\end{tabular}


Table (9): Pertinent of variance components from combined analysis over two locations, genotypic (GCV) and phenotypic (PCV) coefficients of variation and heritabilities $\left(\mathrm{h}^{2}\right)$ in both locations for yield traits

\begin{tabular}{|c|c|c|c|c|c|c|c|c|}
\hline \multicolumn{2}{|c|}{ Parameter } & FLcm & FDcm & FShI & WFg & NoFP & FYPkg & TSS\% \\
\hline \multicolumn{2}{|c|}{$\delta^{2} g$} & 8.346 & 2.364 & 1.745 & 1982.3 & 16.92 & 0.061 & 2.977 \\
\hline \multicolumn{2}{|c|}{$\delta^{2} \mathrm{e}$} & 0.082 & 0.278 & 0.179 & 1.877 & 1.483 & 0.1476 & 0.244 \\
\hline \multicolumn{2}{|c|}{$\delta^{2} l$} & 0.696 & 0.463 & 0.303 & 0.519 & 0.501 & 0.689 & 0.660 \\
\hline \multicolumn{2}{|c|}{$\delta^{2} g \times 1$} & 0.031 & 0.085 & 0.016 & 0.593 & 0.495 & 0.074 & 0.119 \\
\hline \multirow{3}{*}{$\mathbf{L}_{1}$} & PCV\% & 25.49 & 17.96 & 25.03 & 393.91 & 26.75 & 1.80 & 20.28 \\
\hline & GCV\% & 25.29 & 17.42 & 24.14 & 391.32 & 24.36 & 1.01 & 20.20 \\
\hline & $h^{2} \%$ & 0.99 & 0.98 & 0.98 & 0.99 & 0.96 & 0.79 & 0.99 \\
\hline \multirow{3}{*}{$\mathbf{L}_{2}$} & PCV\% & 25.37 & 17.80 & 24.54 & 394.96 & 24.91 & 1.79 & 20.41 \\
\hline & GCV\% & 25.35 & 17.73 & 24.43 & 394.66 & 23.63 & 1.73 & 20.41 \\
\hline & $h^{2} \%$ & 0.99 & 0.99 & 0.99 & 0.99 & 0.98 & 0.98 & 0.99 \\
\hline
\end{tabular}

Polymorphisms detected using RAPD, ISSR, and SCoT Markers

In the present study, five primers of RAPD, ISSR, and SCoT were used to examine the genetic diversity among 14 summer squash genotypes. All primers except (ISSR-HB-11) - demonstrated polymorphism in the tested genomic DNA as indicated by the banding patterns (Fig. 2 and Tables 10, 11, 12). Out of 80 amplified RAPD bands, 68 and 12 bands were polymorphic and monomorphic, respectively (Fig. 2A and Table 10). The total bands per primer varied from 9 to 33 for OP-B17 and OP-C17, respectively. The size of amplified products varied from 122 to $1623 \mathrm{bp}$. In addition, OP-B17 and OP-K01 primers had the highest (30) and lowest (9) number of polymorphic bands. The average of $(\mathrm{P} \%)$ was $85 \%$ across all accessions. The highest $\mathrm{P} \%$ was $100 \%$ for primer OP-B17, and the lowest was $(61.54 \%)$ for primer OP-C13. The average of PIC, EMR, and MI values were 0.72, 11.80, and 9.31 respectively. Meanwhile, primer OP-K01 recorded lowest values for PIC, EMR, and MI $(0.48,6.75$, and 3.22) while; primer OP-B17 recorded the highest values $(0.89,27.27$, and 24.19). The Rp values ranged between 10.17 (OP-C13) to 12.56 (OP-K01) while; the average was 7.77 .

Table (10): Number and types of the amplified DNA bands as well as the polymorphism percentage generated by the five RAPD primers

\begin{tabular}{lccccccccccc}
\hline RAPD & MB & UB & PB & TAB & $\begin{array}{c}\text { FS } \\
\text { (larger) }\end{array}$ & $\begin{array}{c}\text { FS } \\
\text { (smaller) }\end{array}$ & PIC & EMR & MI & P (\%) & Rp \\
\hline OP-B09 & 1.00 & 3.00 & 12.00 & 13.00 & 1312 & 122 & 0.80 & 11.08 & 8.88 & $92.31 \%$ & 5.16 \\
OP-B17 & 0.00 & 4.00 & 9.00 & 9.00 & 1495 & 261 & 0.81 & 9.00 & 7.25 & $100.00 \%$ & 3.50 \\
OP-C13 & 5.00 & 5.00 & 8.00 & 13.00 & 1456 & 356 & 0.61 & 4.92 & 3.00 & $61.54 \%$ & 10.17 \\
OP-C17 & 3.00 & 18.00 & 30.00 & 33.00 & 1623 & 167 & 0.89 & 27.27 & 24.19 & $90.91 \%$ & 7.47 \\
OP-K01 & 3.00 & 2.00 & 9.00 & 12.00 & 983 & 207 & 0.48 & 6.75 & 3.22 & $75.00 \%$ & 12.56 \\
\hline Total & 12.00 & 32.00 & 68.00 & 80.00 & & & 3.58 & 59.02 & 46.53 & $85.00 \%$ & 38.87 \\
\hline Average & 2.40 & 6.40 & 13.60 & 16.00 & & & 0.72 & 11.80 & 9.31 & 0.84 & 7.77 \\
\hline
\end{tabular}

MB monomorphic band, UB unique band, PB polymorphic band, TAB total amplified bands, FS fragment size, PIC polymorphic information content, EMR effective multiplex ratio, $\mathrm{P} \%$, percent of polymorphism, Rp resolving power 
In the same context, the size of amplified ISSR bands ranged from 114 to $1815 \mathrm{bp}$. A total of 36 bands were produced (Fig. 2B and Tables 11). Primers (49A and HB-11) amplified the lowest number of bands (3), and primer (HB-13) amplified the highest number of bands (15). From the detected bands, 25 and 11 were polymorphic and monomorphic bands, respectively. The number of polymorphic bands ranged from 0 (HB-11) to 13 (HB-13), with a mean of 5 bands per locus. The average of $(\mathrm{P} \%)$ was $69.4 \%$ across all the studied genotypes. The highest $(\mathrm{P} \%)$ was $(86.66 \%)$ for primer (HB-13), and the lowest was (0\%) for primer (HB-11). Besides, the average of PIC, EMR and MI parameters were $(0.43,3.86$, and 2.29$)$ respectively. Moreover, the lowest values were 0 for (HB-11), while the highest values were $(0.62,11.27$, and 6.99) for (HB-13) respectively. Finally, the Rp value varied from 3.72 (49A) to 11.29 (HB-13), whereas the mean value was 6.65 distinguishing the studied genotypes.

Table (11): Number and types of the amplified DNA bands as well as the polymorphism percentage generated by the five ISSR primers

\begin{tabular}{lccccccccccc}
\hline ISSR & MB & UB & PB & TAB & $\begin{array}{c}\text { FS } \\
\text { (larger) }\end{array}$ & $\begin{array}{c}\text { FS } \\
\text { (smaller) }\end{array}$ & PIC & EMR & MI & P (\%) & Rp \\
\hline 44B & 2.00 & 2.00 & 5.00 & 7.00 & 1259 & 305 & 0.63 & 3.57 & 2.25 & $71.42 \%$ & 5.12 \\
49A & 1.00 & 0.00 & 2.00 & 3.00 & 406 & 248 & 0.37 & 1.33 & 0.49 & $66.66 \%$ & 3.72 \\
HB-08 & 3.00 & 0.00 & 5.00 & 8.00 & 682 & 114 & 0.55 & 3.13 & 1.72 & $62.50 \%$ & 7.13 \\
HB-11 & 3.00 & 0.00 & 0.00 & 3.00 & 564 & 303 & 0.00 & 0.00 & 0.00 & $0.00 \%$ & 6.00 \\
HB-13 & 2.00 & 6.00 & 13.00 & 15.00 & 1815 & 189 & 0.62 & 11.27 & 6.99 & $86.66 \%$ & 11.29 \\
\hline Total & 11.00 & 8.00 & 25.00 & 36.00 & & & 2.17 & 19.30 & 11.45 & $69.44 \%$ & 33.26 \\
\hline Average & 2.20 & 1.60 & 5.00 & 7.20 & & & 0.43 & 3.86 & 2.29 & 0.57 & 6.65 \\
\hline
\end{tabular}

MB monomorphic band, UB unique band, PB polymorphic band, TAB total amplified bands, FS fragment size, PIC polymorphic information content, EMR effective multiplex ratio, $\mathrm{P} \%$, percent of polymorphism, Rp resolving power

On the other hand, SCoT primers generated 53 markers; among these, 42 were polymorphic, and 11 were monomorphic (Fig. 2C and Table 12). However, primer SCoT 3 scored the lowest number of bands (5) and primer SCoT 4 scored the highest number of bands (18). Amplified band product size varies from $107 \mathrm{bp}$ to 1482 bp. Overall, the percent band polymorphism (PB) identified by these five SCoT primers have a range from 60 (SCoT 3) to 88.8 (SCoT4) with an average of 79.2\%. The bands identified by the 42 polymorphic marker pairs varied from3 (SCoT 3) to 16 (SCoT 4) with an average of 8.40 bands per locus. Within the examined germplasm, Rp varied from 3.12 (SCoT 6) to 10.20 (SCoT1) with a mean of 6.76 for the 5 SCoT markers, indicating a wide variation in resolving power of the markers, indicating that the primers with high Rp can be further used for DNA fingerprinting and varietal discrimination studies. On the other hand, in the studied germplasm, SCoT 4 showed the maximum PIC, EMR and MI values of $0.79,14.22$, and 11.30 , respectively, and SCoT 3 shows the least PIC, EMR and MI values of $0.45,1.80$, and 0.81 , respectively.

Table (12): Number and types of the amplified DNA bands as well as the polymorphism percentage generated by the five SCoT primers

\begin{tabular}{lccccccccccc}
\hline SCoT & MB & UB & PB & TAB & $\begin{array}{c}\text { FS } \\
\text { (larger) }\end{array}$ & $\begin{array}{c}\text { FS } \\
\text { (smaller) }\end{array}$ & PIC & EMR & MI & P (\%) & Rp \\
\hline SCoT 1 & 3.00 & 5.00 & 12.00 & 15.00 & 883 & 107 & 0.66 & 9.60 & 6.33 & $80.00 \%$ & 10.20 \\
SCoT 2 & 3.00 & 1.00 & 6.00 & 9.00 & 1482 & 263 & 0.58 & 4.00 & 2.31 & $66.67 \%$ & 7.61 \\
SCoT 3 & 2.00 & 2.00 & 3.00 & 5.00 & 351 & 158 & 0.45 & 1.80 & 0.81 & $60.00 \%$ & 5.49 \\
SCoT 4 & 2.00 & 6.00 & 16.00 & 18.00 & 1049 & 205 & 0.79 & 14.22 & 11.30 & $88.89 \%$ & 7.40 \\
SCoT 6 & 1.00 & 1.00 & 5.00 & 6.00 & 830 & 279 & 0.73 & 4.17 & 3.08 & $83.33 \%$ & 3.12 \\
\hline Total & 11.00 & 15.00 & 42.00 & 53.00 & & & 3.22 & 33.79 & 23.84 & $79.25 \%$ & 33.82 \\
\hline Average & 2.20 & 3.00 & 8.40 & 10.60 & & & 0.64 & 6.76 & 4.77 & 0.76 & 6.76 \\
\hline
\end{tabular}

MB monomorphic band, UB unique band, PB polymorphic band, TAB total amplified bands, FS fragment size, PIC polymorphic information content, EMR effective multiplex ratio, $\mathrm{P} \%$, percent of polymorphism, Rp resolving power 
In this study, it was intriguing to observe the positive and negative markers. Tables (13 and 14) showed that 55 positive and 2 unique negative bands were amplified using RAPD, ISSR and SCoT markers in the studied genotypes. RAPD markers recorded the highest unique bands (33) followed by SCoT (15) and ISSR (9). It was clear that primer OP-C17 amplified the highest number of unique markers (18 amplicons); meanwhile, the lowest number of unique markers was detected by primers SCoT 2 and SCoT6 (1 amplicon) while, primers 49A, HB-08, and HB-11 do not generate any unique bands. Notably, across the studied genotypes it was obvious that genotype number 1 produced highest number of unique marker (11) out of which six, one and ten markers was amplified by RAPD, ISSR and SCoT markers respectively. Followed by genotypes 10 and 14 generated seven unique bands for each of them. Furthermore, genotypes number 3 and 11 were produced the lowest number of unique bands (1) for each of them. Generally, the obtained results clearly show a significant amount of polymorphism among the tested genotypes.

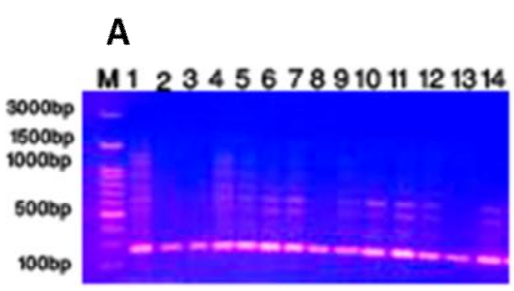

OP-B9

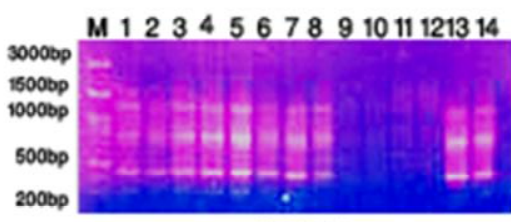

OP-B17

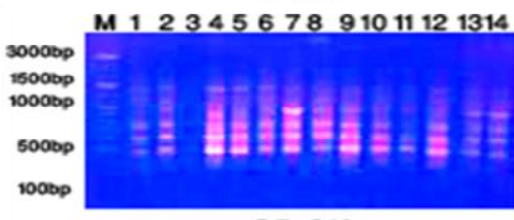

$\mathrm{OP}-\mathrm{C13}$

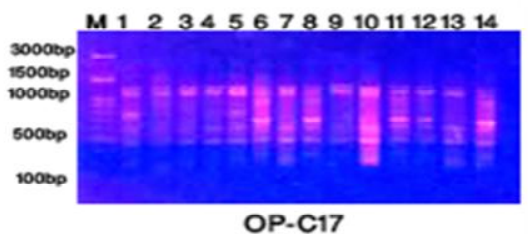

OP-C17

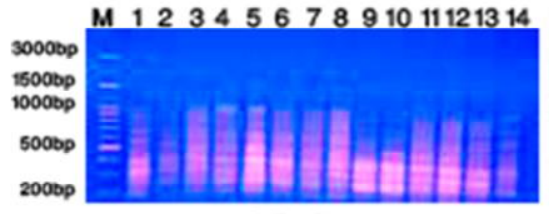

OP-K1

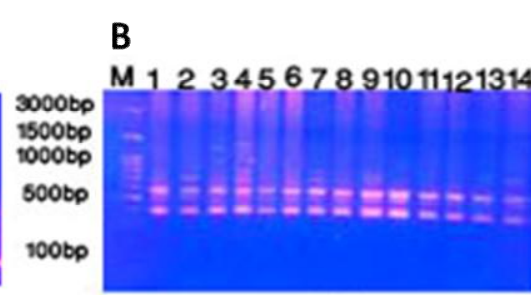

44B

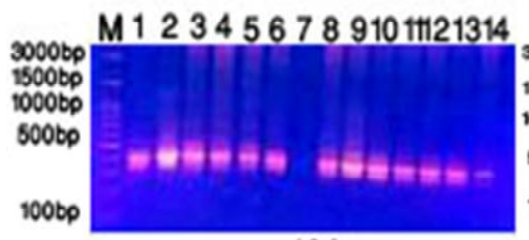

$49 \mathrm{~A}$

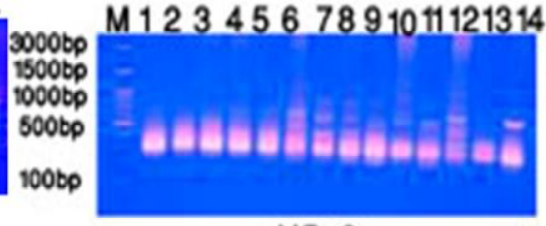

$\mathrm{HB}-8$

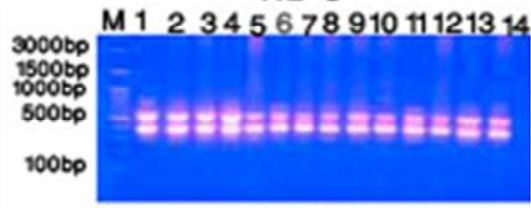

HB-11

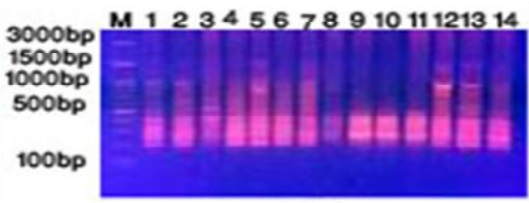

HB-13
C

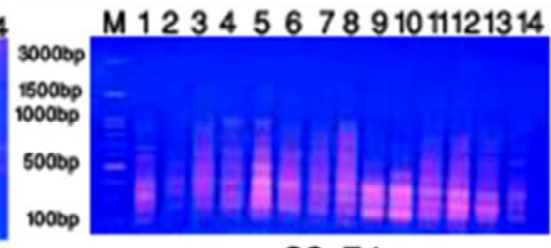

SCOT 1

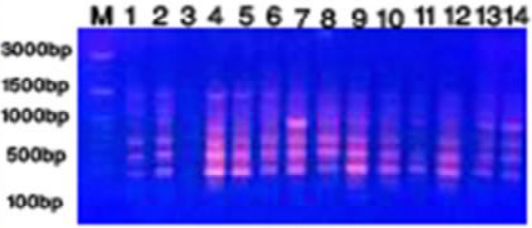

SCOT 2

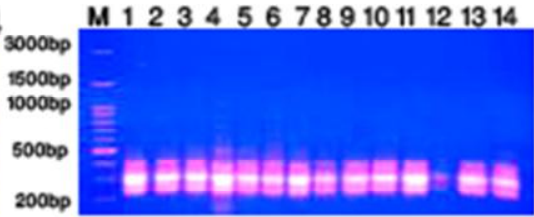

SCoT 3

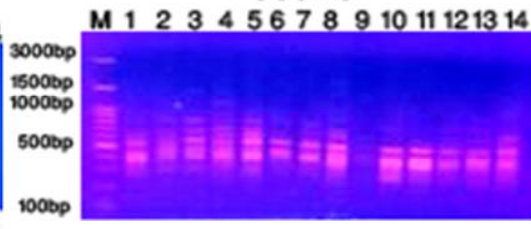

SCOT 4

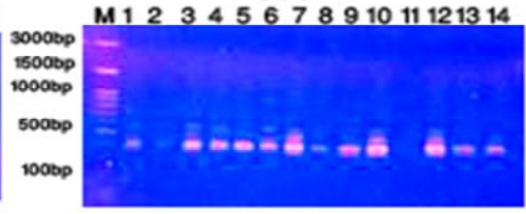

SCoT 6

Figure (2): (A) RAPD (B) ISSR (C) SCoT patterns of the fourteen squash genotypes revealed by five primers per each

\section{Dendrogram construction and principal component analysis}

A similarity matrix based on the combined RAPD, ISSR, SCoT data was used to estimate the level of relatedness among the studied squash landraces (Table 15). The obtained matrix showed that the Jaccard's coefficient of similarity values (GS), ranging from 0.45 to 0.80 , figured a moderate genetic diversity level within the studied germplasm. The smallest similarity value $(0.45)$ suggested the high variance between SQ1 and SQ10. The maximum similarity value $(0.80)$ was found between SQ11 and SQ12, indicating that both cultivars were the most similar. On the other hand, genetic relationships as determined by cluster analysis and principal component analysis (PCA) for RAPD, ISSR, SCoT, and pooled allelic data (RAPD+ISSR + $\mathrm{SCoT}$ ), are shown in (Fig 3A, 3B, 3C, 3D ) respectively. Cluster analysis using RAPD, ISSR, and SCoT data grouped the 14 squash genotypes into four, three, and two distinct clusters, respectively (Fig. 3A, 3B, 3C). UPGMA dendrograms obtained by the three markers were relatively similar, and most of the landraces were placed in their respective groups. 
Table (13): Number of positive and negative unique RAPD, ISSR and SCoT markers recorded in squash genotypes

\begin{tabular}{|c|c|c|c|c|c|c|c|c|c|c|c|c|c|c|c|c|}
\hline & $\begin{array}{c}\text { Marker } \\
\text { type }\end{array}$ & Primer & SQ1 & SQ2 & SQ3 & SQ4 & SQ5 & SQ6 & SQ7 & SQ8 & SQ9 & SQ10 & SQ11 & SQ12 & SQ13 & SQ14 \\
\hline \multirow{14}{*}{ 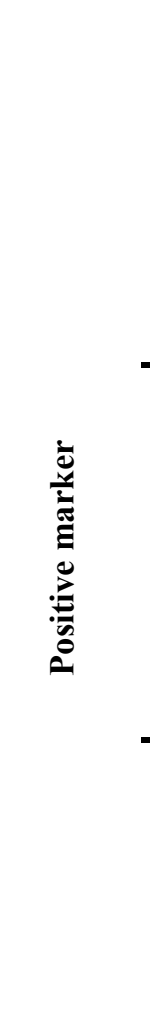 } & \multirow{5}{*}{ 军 } & OР-B09 & 122 & - & - & - & - & - & - & - & 321,250 & - & - & - & - & - \\
\hline & & OP-B17 & 1495 & - & - & - & - & - & - & - & - & 558 & 405 & - & 1018 & - \\
\hline & & OP-C13 & - & - & & 1087 & - & - & - & 1117 & 965 & 1024 & - & 1053 & - & - \\
\hline & & OP-C17 & $\begin{array}{c}679,34 \\
167\end{array}$ & - & - & - & 849 & 1056 & 219 & 893 & 545 & $\begin{array}{c}610,323,2 \\
59,202\end{array}$ & - & - & 239 & $\begin{array}{c}871,718 \\
, 484,33\end{array}$ \\
\hline & & OP-K01 & 976 & 382 & - & - & - & - & - & - & - & - & - & - & - & - \\
\hline & \multirow{5}{*}{$\underline{\mathscr{a}}$} & 44B & - & - & 1221 & 1259 & - & - & - & - & - & - & - & - & - & - \\
\hline & & 49A & - & - & - & - & - & - & - & - & - & - & - & - & - & - \\
\hline & & HB-08 & - & - & - & - & - & - & - & - & - & - & - & - & - & - \\
\hline & & HB-11 & - & - & - & - & - & - & - & - & - & - & - & - & - & - \\
\hline & & HB-13 & 1027 & 963 & - & - & $\begin{array}{c}1815 \\
746 \\
\end{array}$ & - & 873 & - & - & - & - & - & - & 822 \\
\hline & \multirow{5}{*}{ 它 } & SCoT 1 & 107 & - & - & - & 122 & - & 703 & 802,660 & - & - & - & - & - & - \\
\hline & & SCoT 2 & - & - & - & - & - & - & - & - & - & - & - & 650 & - & - \\
\hline & & SCoT 3 & 266 & - & - & 351 & - & - & - & - & - & - & - & - & - & - \\
\hline & & SCoT 4 & 262,205 & - & - & 1049 & - & - & 702 & 659 & - & - & - & - & - & 470 \\
\hline \multirow{4}{*}{$\begin{array}{c}\text { Negative } \\
\text { marker }\end{array}$} & & SCoT 6 & - & - & - & - & - & 830 & - & - & - & - & - & - & - & - \\
\hline & RAPD & OP-K01 & - & - & - & - & - & - & - & - & - & 501 & - & - & - & - \\
\hline & ISSR & HB-13 & - & - & - & - & - & - & - & 267 & - & - & - & - & - & - \\
\hline & Total & & 11 & 2 & 1 & 4 & 4 & 2 & 4 & 6 & 4 & 7 & 1 & 2 & 2 & 7 \\
\hline
\end{tabular}


Table (14): Comparison among studied RAPD, ISSR and SCoT primers

\begin{tabular}{cccccc}
\hline $\begin{array}{c}\text { Primer } \\
\text { Name }\end{array}$ & $\begin{array}{c}\text { Total } \\
\text { Bands }\end{array}$ & Monomorphic Bands & Polymorphic Bands & $\begin{array}{c}\text { Unique } \\
\text { Bands }\end{array}$ & Polymorphism \% \\
\hline RAPD & 80 & 12 & 68 & 33 & $85.00 \%$ \\
ISSR & 36 & 11 & 25 & 9 & $69.44 \%$ \\
SCoT & 53 & 11 & 42 & 15 & $79.25 \%$ \\
\hline Total & 169 & 34 & 135 & 57 & $79.88 \%$ \\
\hline
\end{tabular}
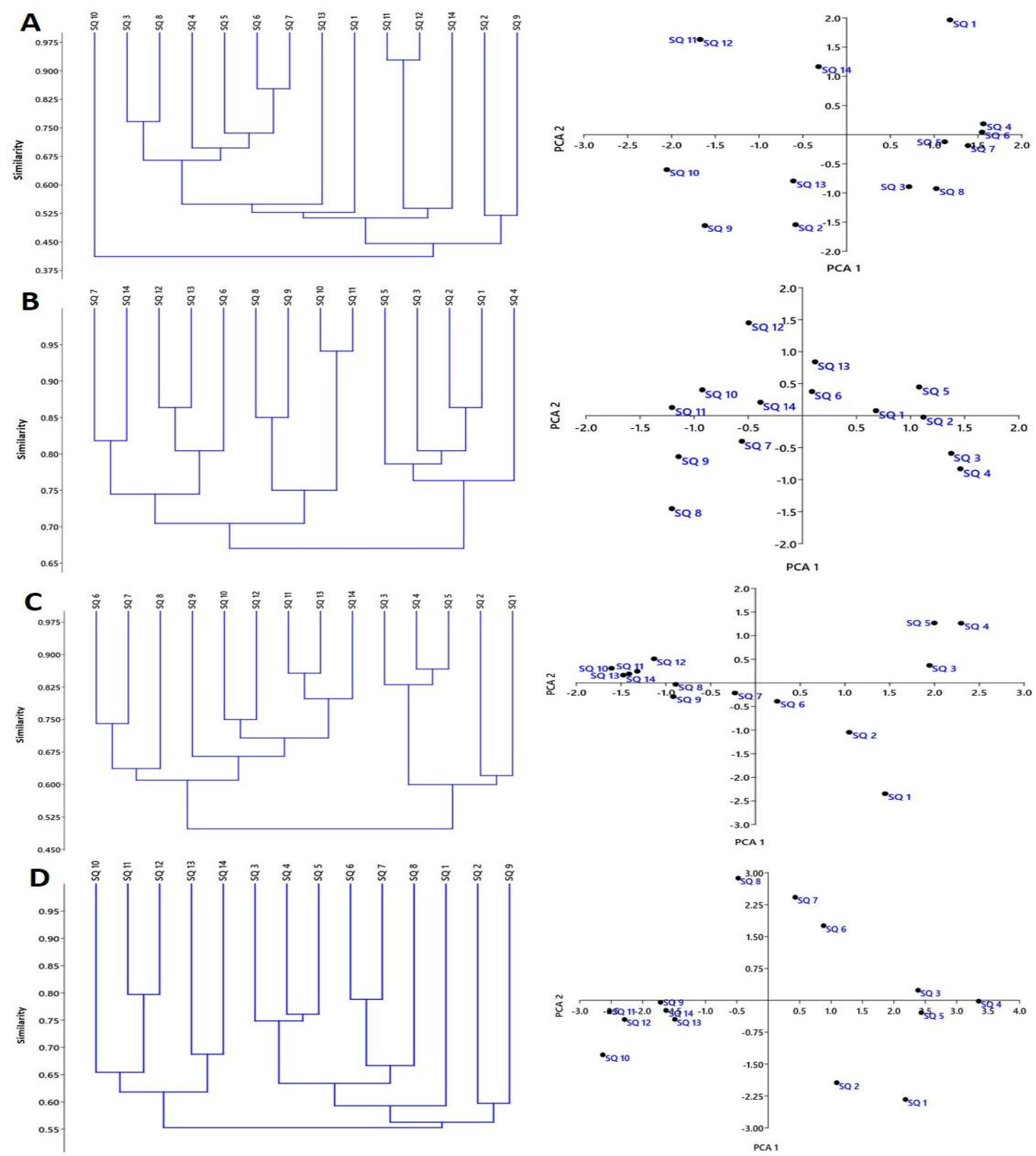

Figure (3): Dendrogram and PCA of (A) RAPD (B) ISSR (C) SCoT (D) combined data analysis of 14 squash genotypes 
Cluster analysis on a combined set of RAPD, ISSR, and SCoT genotyping data classified summer squash landraces in two main distinct groups, which was further divided into four sub-clusters as depicted in (Fig. 3D). Subcluster I comprised two germplasm, subcluster II comprised seven germplasm, subcluster III includes two genotypes, and subcluster IIII involves 3 different genotypes. Notably, the PCA results further confirmed the grouping identified from the constructed UPGMA dendrogram for all the studied markers as well as the combined one. Additionally, (Fig. 4) explained cluster analysis based on the combination of yield and molecular data; the results revealed that all studied genotypes clustered into two main groups and five subgroups. In this regard, some of the clustered genotypes as revealed by pooled allelic data were similar to the clustered genotypes in (Fig. 3D) such as genotypes (SQ2 \& SQ9) that represents highest values of fruit diameter and average fruit weight. Also, genotypes (SQ6 \& SQ7) represent the highest fruit yield/plant and fruit shape values.

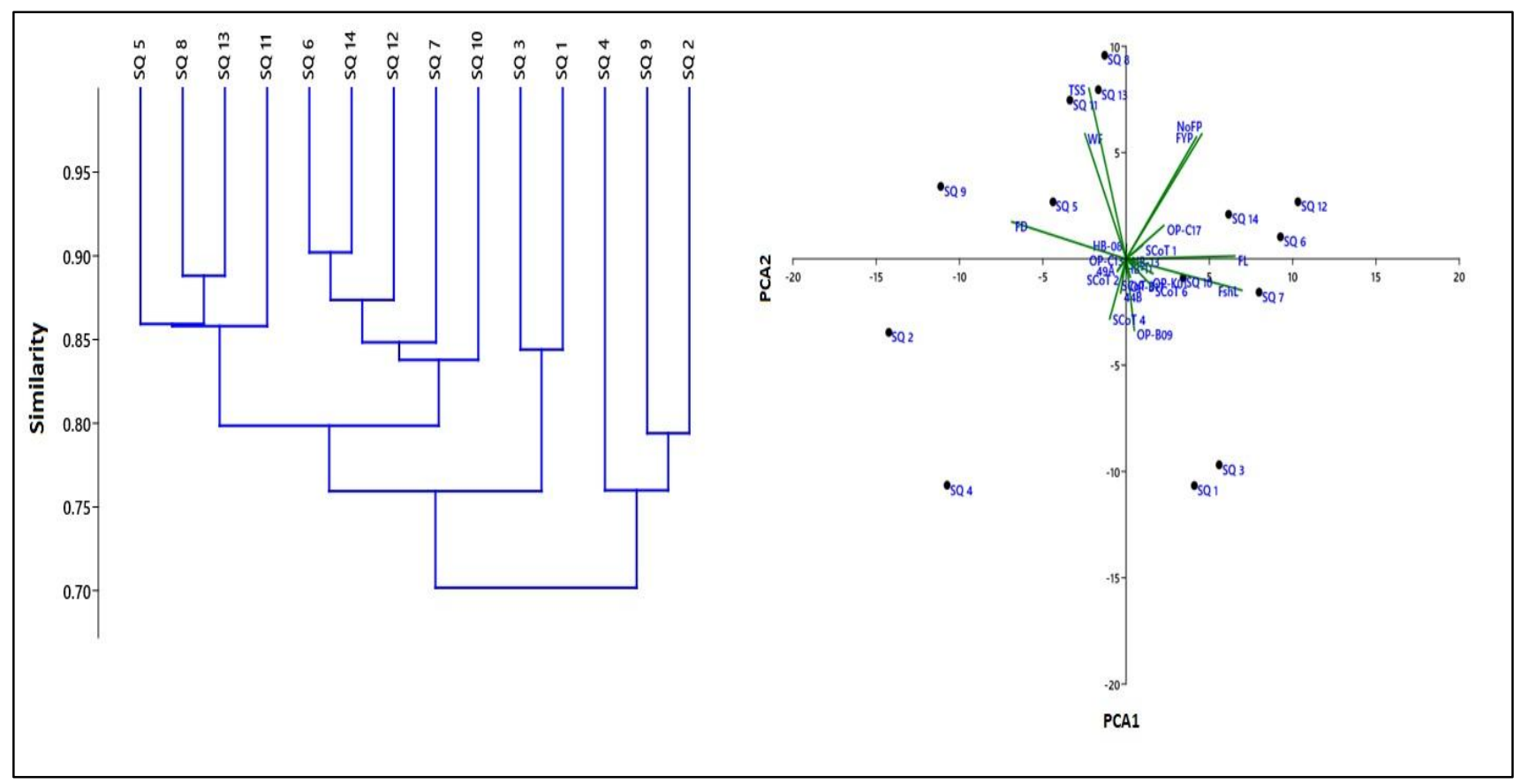

Figure (4): Cluster and PCA analysis based on combined molecular and yield data for 14 squash genotypes

Table (15): Similarity index of RAPD, ISSR, and SCoT combination analysis of 14 squash genotypes

\begin{tabular}{|c|c|c|c|c|c|c|c|c|c|c|c|c|c|c|}
\hline & SQ1 & SQ2 & $\mathrm{SQ} 3$ & SQ 4 & SQ 5 & SQ 6 & SQ7 & SQ 8 & SQ9 & SQ 10 & SQ 11 & SQ 12 & SQ 13 & SQ 14 \\
\hline SQ1 & 1 & & & & & & & & & & & & & \\
\hline SQ2 & 0.59 & 1 & & & & & & & & & & & & \\
\hline $\mathrm{SQ}_{3}$ & 0.62 & 0.67 & 1 & & & & & & & & & & & \\
\hline SQ 4 & 0.63 & 0.59 & 0.74 & 1 & & & & & & & & & & \\
\hline SQ 5 & 0.61 & 0.64 & 0.76 & 0.76 & 1 & & & & & & & & & \\
\hline SQ 6 & 0.62 & 0.59 & 0.69 & 0.66 & 0.69 & 1 & & & & & & & & \\
\hline SQ7 & 0.59 & 0.54 & 0.66 & 0.65 & 0.64 & 0.79 & 1 & & & & & & & \\
\hline SQ 8 & 0.50 & 0.52 & 0.62 & 0.54 & 0.56 & 0.66 & 0.68 & 1 & & & & & & \\
\hline SQ 9 & 0.46 & 0.60 & 0.53 & 0.48 & 0.51 & 0.59 & 0.59 & 0.59 & 1 & & & & & \\
\hline SQ 10 & 0.45 & 0.50 & 0.47 & 0.46 & 0.51 & 0.53 & 0.56 & 0.48 & 0.62 & 1 & & & & \\
\hline SQ 11 & 0.52 & 0.49 & 0.55 & 0.50 & 0.55 & 0.62 & 0.60 & 0.60 & 0.63 & 0.68 & 1 & & & \\
\hline SQ 12 & 0.52 & 0.48 & 0.55 & 0.50 & 0.56 & 0.62 & 0.60 & 0.55 & 0.55 & 0.63 & 0.80 & 1 & & \\
\hline SQ13 & 0.53 & 0.60 & 0.61 & 0.52 & 0.58 & 0.60 & 0.61 & 0.61 & 0.62 & 0.60 & 0.65 & 0.65 & 1 & \\
\hline SQ 14 & 0.54 & 0.53 & 0.53 & 0.50 & 0.56 & 0.62 & 0.62 & 0.57 & 0.55 & 0.55 & 0.64 & 0.62 & 0.69 & 1 \\
\hline
\end{tabular}




\section{DISCUSSION}

Knowing the genetic divergence of a crop is vital for parental selection to maximize genetic improvement. More precise and integral characterization of the genotypes and genetic variability patterns could help determine future breeding strategies. In this study, 14 summer squash genotypes were evaluated for the genetic diversity using some yield traits along with 15 RAPD, ISSR and SCoT primers. Morphological and molecular characterization is essential for elucidating the genetic relationships among the different groups of the species of Cucurbita and provides complementary information with greater power of resolution for genetic diversity analyses (Barzergar et al., 2013).

Some genotypes constantly behaved at both locations and others fluctuated from location to another, meaning that the detected differences due to genotypes were so pronounced compared with locations, reflecting the relatively high stability of the various genotypes over locations and suggesting that the superior genotypes can be selected and recommended for growers (Valdés-Restrepo et al., 2013; Rani, 2014; Abdein et al., 2017). Genotype $\times$ location interactions were significant for all traits reflecting the drastic effect of varying environments among locations besides the differential response of genotypes in these environments. The location had a significant impact on the relative genotypic potential of these traits. These results are in general agreement with those reported by Abd El-Salam et al. (2010), Kumar and Wehner (2011), Blessing et al. (2012) and El-Khatib (2013) were found similar results, and reported significant differences for all studied characters among the different genotypes, These results suggest that it is necessity for evaluation squash genotypes in large diverse environments in breeding program to select the best genotype suitable for particular environment (Rani, 2014). Salama et al. (2019) found that the varietals differences among the studied cultivars may be due to the heredity differences. They may also be due to the differences among them in their yield attributes.

Genetic variation $\left(\sigma^{2} \mathrm{~g}\right)$ was large in magnitude compared to error one $\left(\sigma^{2} \mathrm{e}\right)$ in all studied traits, reflecting the genetic differences among genotypes. On the other hand, small differences were observed between PCV\% and GCV\% for most traits, indicating the importance of the genetic effects in controlling the inheritance of traits under these environments and referring to highly genotypic variances resulted in high or moderate estimates of broad-sense heritabilities which, in turn, suggesting that phenotypic selection could be efficient. The high heritability for studied characters indicates there is less influence of environment. It reveals that these characters were governed by additive genes and selection for improvement under these environments would be beneficial. Results are in general agreement with those reported by Shamloul (2002); Abd El-Hadi and ElGendy (2004); Abd El-Hadi et al. (2005) and El-Khatib (2013). In cucumber, Mishra et al. (2007) reported maximum heritability for yield per plant followed by number of fruits per plant. These finding led to the conclusion that the selection for such traits must be done under both regions in different seasons and sowing dates.

On the other hand, the three types of DNA markers employed in this study, RAPD, ISSR, and SCoT, differ in the nature of the evolutionary mechanisms underlying their variation and their distribution in the genome (Osman and Ali 2020). According to our results, the detected average of polymorphism percent was $85 \%, 79.25 \%$, and 69.44 for RAPD, ISSR, and SCoT markers, respectively, indicating the very high discriminating ability of the studied techniques and genotypes. The recorded polymorphism percentage in this research was higher than Al-Tamimi (2014) (63.6), Kiani and Siahchehreh (2017) (61.6\%), and Xanthopoulou et al. (2015) (62.82), while was lower than the polymorphism percentage reported by Panyanitikoon et al. (2018) (93\%), Abd ElHadi et al. (2017) (80.5\%) and Bhawna et al. (2017) $(87.63 \%)$ in Cucurbitaceae. Apparently, from (Table 14) RAPD marker revealed the highest polymorphism percentage and the total amplified bands as well as the unique bands, followed by SCoT and ISSR markers. The latter point indicates RAPD marker's potential for identifying and assessing genetic variations among squash genotypes and provide several choices for developing a successful breeding program to improve summer squash. Yildiz et al. (2011) found that polymorphism percentage of RAPD primers was higher than ISSR and SRAP marker when studied the genetic diversity among 63 melon (Cucumis melo L.) genotypes. In the same trend, Xanthopoulou et al. (2015) found that SCoT and ISSR markers were able to discriminate between 36 summer squash landraces. The level of polymorphism generated by SCoT markers was higher ISSR markers. Four parameters (PIC, EMR, MI and $\mathrm{Rp}$ ) we recomputed to assess the efficiency of studied markers. EMR is the product of the fraction of polymorphic bands and the number of polymorphic bands and therefore the higher polymorphism provides higher EMR. Across all the studied primers, OP-B17 showed the maximum $\mathrm{P} \%(100 \%)$ followed by primer OP-C17 $(90.9 \%)$ which also recorded the maximum values for (PIC, EMR, MI), while primer HB-11 showed the least values for (P\%, PIC, EMR, MI) parameters. The Marker index results are higher as compared with other investigations (Barzergar et al., 2013) SSR; 8.69, (Xanthopoulou et al., 2015) SCoT; 3.094 and ISSR; 1.33. Likewise, our estimated PIC values is more than those reported by Panyanitikoon et al. (2018) RAPD; 0.45; Kiani and Siahchehreh (2017) ISSR; 0.32 and Xanthopoulou et al. (2015) SCoT; 0.309 . The resolving power of each primer/marker was estimated in order to determine the most informative ones for the discrimination between studied summer squash landraces.OP-K01 primer showed the maximum Rp value 12.56 while, SCoT 6 showed the least Rp value 3.12 , indicating that OP-K01 primer can be further used for DNA fingerprinting and varietal discrimination studies. Our estimates are higher than Rp values presented in similar Cucurbita studies. For 
example, (Inan et al., 2012) ISSR; 6.6, (Xanthopoulou et al., 2015) SCoT; 10.0 and ISSR; 5.66.Very interestingly, in the present research, the higher unique bands detected in the studied squash genotypes that reflect higher genetic distinctness and could be used in the genotype discrimination. The presence of unique ISSR markers may be regarded as markers for the authentication of genetic resources (Badr et al., 2014). UPGMA dendrogram is accessible in (Fig 3), which can be used to recognize the genetic relationship between the germplasm. Kiani and Siahchehreh (2017) reported that the similarity values ranging from 0.14 to 0.70 using ISSR markers in C. pepo. landraces which indicates less diversity comparing with our results, while similarity index that represented by Yildiz et al. (2011) was ranging between 0.46 and 0.96 using ISSR, SRAP, and RAPD which was higher than our recorded similarity index. Furthermore, in this study the dendrograms and genetic distance matrices produced from the RAPD, ISSR and SCoT data were almost similar, this result is in line with that of (Xanthopoulou et al. 2015) and (Panyanitikoon et al. 2018). It is worthy to mention that the dendrogram showed clustering of germplasm was not according to geographical concordance, this is probably due to cross pollinated nature of summer squash. This result was congruence in line with Bhawna et al. (2017) in bottle gourd. Contrary, Panyanitikoon et al. (2018) showed that the 38 cucumber accessions were divided into two main clusters and this grouping was in good agreement with country of origin. The results obtained by principal coordinate analysis were consistent with those of cluster analysis. However, cluster analysis could supply more abundant information's than principal coordinate analysis on revealing the relationship among the closely related genotypes. It was concluded from the findings of (Fig. 4) that genotypes that had highest values of some yield traits located together in the same clusters, these result showed that molecular analysis were correlated with the yield characteristics. In addition, the obtained PCA further supported the dendrogram results in a robust way, similar results were found by Kiani and Siahchehreh (2017). Overall, marker analysis showed a number of differences in the size and number of bands among the species, which means that there are genetical differences among the studied cucurbit lines. Besides, the data deduced that the RAPD primers (OP-B17 and OP-C17) were the most efficient for discriminating the studied genotypes genetically.

\section{CONCLUSION}

The current study presented high variations for yield and molecular profile in terms of different genotypes. The 14 Cucurbita pepo genotypes evaluated in this study showed highly significant variability in both locations for all studied yield traits. In the same context, the studied markers generated 57 unique bands, out of which (33) bands were developed by RAPD followed by SCoT (15) and ISSR (9). Furthermore, OP$\mathrm{C} 17$ and ESKANDARANI genotype produced the highest number of unique markers. The high genetic diversity found could be used in breeding programs to obtain new cultivars and provide relevant information for diversity conservation. Moreover, this research revealed that characterization based on both yield and molecular markers is essential for elucidating the genetic relationships of ecotypes within this Cucurbita species.

\section{REFERENCES}

Abd El-Hadi, A. H. and S. E. A. El-Gendy (2004). Effect of genotypes by locations interaction on economical traits of squash. J. Agric. Sci., Mansoura Univ., Egypt, 29(10): 5667-5687.

Abd El-Hadi, A. H., A. M. El-Adl, H. M. Fathy and M. A. Abdein (2014). Heterosis and genetic behavior of some yield and yield component traits in squash (Cucurbita pepo L.). Alexandria Science Exchange Journal, Vol. 35, No. 3: 178-189.

Abd El-Hadi, A. H., A. M. El-Adl, M. S. Hamada and M. A. Abdein (2005). Heterosis and genetic behavior of some quantitative traits of squash at different environmental conditions. Alexandria Journal of Agricultural Research, Alex. Univ., 50(2): 107-120.

Abd El-Hadi, A. H., M. H. Abd El-Aziz, M. A. AbdAlla and M. G. Ashak (2017). Molecular and phenotypic evaluation of some summer squash inbred lines. J. Agric. Chem. and Biotechn., Mansoura Univ., 8(12): 281-287.

Abd El-Moneim, D. (2019). Characterization of ISSR and SCoT Markers and TaWRKY gene expression in some Egyptian wheat genotypes under drought stress. J. of Plant Production Sciences; Suez Canal Uni., V. 8(1): 31-46.

Abd El-Salam, M. M., I. S. El-Demardash and A. H. Hussein (2010). Phenotypic stability analysis, heritability and protein patterns of snake cucumber genotypes. Journal of American Science, 6(12): 503-507.

Abd-Alrahman, A. M. M, A. A. Gad, A. Bardisi and H. G. Zyada (2020). Response of vegetative growth, leaf pigments, yield and fruit quality of some summer squash cultivars grown in sandy soil to foliar spray with some Antioxidants. Zagazig J. Agric. Res., 47(3): 693-706.

Abdein, M. A. (2018). Genetic diversity between pumpkin accessions growing in the Northern Border Region in Saudi Arabia based on biochemical and molecular parameters. Egyptian Journal Botany, 58(3): 463-476.

Abdein, M. A. (2005). Quantitative genetics of some economic traits in squash (Cucurbita pepo L). M. Sc. Thesis, Fac. of Agric., Mansoura Univ. Egypt.

Abdein, M. A., D. Abd El-Moneim, S. S. Taha, W. S. M. Al-Juhani and S. E. Mohamed (2018). Molecular characterization and genetic relationships among some tomato genotypes as revealed by ISSR and SCoT markers. Egypt. J. Genet. Cytol., 47(1): 139-159. 
Abdein, M. A., H. F. Hassanand D. M. Hikal (2017). General performance, combining abilities and heritability of yield and yield component traits in pumpkin (Cucurbita moschata Poir.) at different conditions. KMITL Sci. Tech. J., Vol. 17(1): 121-129.

Al-Araby, A. A. (2004). Breeding studies on cucumber crop (Cucumis sativus L.). M.Sc. Thesis, Fac. of Agric., Tanta Univ., Egypt.

Al-Araby, A. A. (2010). Estimation of heterosis, combining ability and heritability in intervarietal crosses of summer squash (Cucurbita pepo L.). Ph.D. Thesis, Fac. of Agric., Tanta Univ., Egypt.

Al-Brifcany, M. T. S. O. (2015). Estimation of heterosis and nature of gene action for some economical traits in squash (Cucurbita pepo L.). M.Sc. Thesis, Fac. of Agric., Mansoura Univ., Egypt.

Al-Tamimi, A. J. T. (2014). Genetic fingerprint of some Cucurbita pepo (summer squash) genotypes using molecular and biochemical techniques Magazin of Al-Kufa University for Biology, Vol. 6, No (1): 1-13.

Anderson, J. A., G. A. Churchill and J. E. Autrique (1993). Optimizing parental selection for genetic linkage maps. Genome, 36: 181-186.

Athanasios, L.T., O. Koutita and A. Anastasiadou (2009). Description and analysis of genetic diversity among squash accessions. Braz Arch Biol. Technol., 52: 271-283.

Badr, A., H. El-Shazly and M. Sakr (2014). Role of biotechnology in conservation and sustainable use of medicinal plants in the arid regions. In: Recent Progress in Medicinal Plants. Govil J.N., (Ed.). Studium Press, India and USA., pp: 317-333.

Barzergar, R., G. Peyvast, A. M. Ahadi, B. Rabiei, A. A. Ebadi and A. Babagolzadeh (2013). Biochemical systematic, population structure and genetic variability studies among Iranian Cucurbita (Cucurbit pepo L.) accessions, using genomic SSRS and implications for their breeding potential. Biochemical Systematic and Ecology, 50: 187-198.

Bhawna, M. Z., L. Arya and M. Verma (2017). Use of SCoT markers to assess the gene flow and population structure among two different population of bottle gourd. Plant Gene, 9: 8086.

Blessing, C. A., M. I. Uguru and B. C. Oyiga (2012). Genetic variability and inter-relationship among some Nigerian pumpkin accession (Cucurbita spp). International Journal of Plant Breeding, 6(1): 34-41.

Collard, B. C. Y and D. J. Maackill (2009). Start Codon Targted (SCoT) polymorphism: a simple novel DNA marker technique for generating gene targeted markers in plants. Plant Mol. Bio., 27: 86-93.

Davis, J. C. (1986). Statistics and data analysis in geology. John Wiley \& Sons, New York., 832 p.
Dijkhuizen, A., W. C. Kennard, M. J. Havey and J. E. Staub (1996). RFLP variation and genetic relationships in cultivated cucumber. Euphtica., 90: 79-87.

El-Khatib, E. H. (2013). Genetic behavior of some economical traits in squash (Cucurbita pepo L.). M.Sc. Thesis, Fac. of Agric., Mansoura Univ., Egypt.

Fayeun, L. S., A. C. Odiyi, S. C. O. Makinde and O. P. Aiyelari (2012). Genetic variability and correlation studies in the fluted pumpkin (Telfairia occidentalis Hook F.). Journal of Plant Breeding and Crop Science, 4(10): 156160.

Ferreira, M. F., M. A. Queiroz, L. T. Braz and R. T. B. Vencovsky (2003). Genotypic, phenotypic and environmental correlation among agronomic traits and the consequences for watermelon breeding. Horticultura - Brasileira, 21(3): 438442.

Ferriol, M., B. Picó and F. Nuez (2003). Genetic diversity of some accessions of Cucurbita maxima from Spain using RAPD and SBAP markers. Genetic Resources and Crop Evolution, 50: 227-238.

Gomez, A. K. and A. A. Gomez (1984). Statistical Procedures for Agricultural Research. $2^{\text {nd }}$ ed. John Wiley \& Sons Pub., pp.139-153.

Heikal, H. A., H. S. Abdel-Razzak and E. E. Hafez (2008). Assessment of genetic relationships among and within Cucurbita species using RAPD and ISSR markers. J. Appl. Sci. Res., 4(5): 515-525.

Hussein, E. H. A., A. A. Mohamed, S. Attia and S. S. Adawy (2006). Molecular characterization and genetic relationships among cotton genotypes 1- RAPD, ISSR and SSR analysis. Arab J. of biotech., 9: 313-328.

Inan, N., M. Yildiz, S. Sensoy, S. Kafkas and K. Abak (2012). Efficacy of ISSR and SRAP techniques for molecular characterization of some Cucurbita genotypes including naked (hullless) seed pumpkin. J. Anim. Plant Sci., 22(1): 126-136.

Jackson, M. L. (1958). Soil Chemical Analysis. Prentice hall Inc. Englewood Cliffs, N.J., U.S.A.

Katzir, N., Y. Tadmor, G. Tzuri, E. Leshzeshen, N. Mozes-Daube, Y. Danin-Poleg and H. S. Paris (2000). Further ISSR and preliminary SSR analysis of relationships among accessions of Cucurbita pepo. International Society for Horticultural Science (ISHS). pp 433-440.

Kiani, G. and M. Siahchehreh (2017). Diversity in squash varieties assessed by ISSR markers, International Journal of Vegetable Science, 23(5): 430-437.

Kumar, R. and T. Wehner (2011). Inheritance of fruit yield in two watermelon populations in North Carolina Euphytica, 182(2): 275-283.

Mady, E. A., A. A. D. Helaly, A. N. A. El-Hamd, A. Abdou, S. A. Shanan and L. E. Craker (2013). Genetic diversity assessment of summer 
squash landraces using molecular markers. Mol.Biol. Rep., 40(7): 4269-4274.

Matlob, A. N., E. Sultan and K. S. Abdul (1989). Vegetable Production. Part one and two. Dar Al-Kutub Publication, Mosul Univ., Iraq. (In Arabic).

Mishra, G., J. R. Yadav, N. S. Parihar, J. K. Yadav, S. Kumar and Y. Alok (2007). Study on heritability and genetic advance in cucumber (Cucumis sativus L.). Progressive Research, 2(1-2): 187-198.

Mohammed, A. R. S. (1996). A study on the effect of different levels of Boron and hand pollination on growth, yield and mineral composition of squash plants (cv. Mullah-Ahmed). Ph.D. Thesis Mosul Univ., College of Agriculture and Forestry, Iraq. (In Arabic).

Nadeem, M. A., M. A. Nawaz and M. Q. Shahid (2018). DNA molecular markers in plant breeding: current status and recent advancements in genomic selection and genome editing. Biotechnol. Biotechnol. Equip., 32: 261-285.

Nassar, K. E. M., H. A. El-Shaboury and A. E. ElSonbaty (2019). Impact of potassium and manganese on the quantity and quality yields of squash (Cucurbita pepo L.). Menoufia J. Soil Sci., Vol. 4: 57- 69.

Ntuli, N. R., A. M. Zobolo, P. B. Tongoona and N. W. Kunene (2013). Genetic diversity in Cucurbita pepo landraces from Northern KwaZulu-Natal, South Africa, revealed by random amplified polymorphic DNA (RAPD) markers, African Journal of Biotechnology, 12(44): 6253-6261.

Osman, S. A. and H. B. M. Ali (2020). Genetic diversity of five Lathyrus species using RAPD, ISSR and SCoT markers. Asian J. Plant Sci., 19: 152-165.

Ovesna, J., K. Polakova and L. Lisova (2002). DNA analyses and their applications in plant breeding. Czech. J. Genet. Plant Breed., 38: 29-40.

Panyanitikoon, H., C. Khanobdee, C. Jantasuriyarat and S. Samipak (2018). Genetic variation in cucumber (Cucumis sativus L.) germplasm assessed using random amplified polymorphic DNA markers. Agric. Nat. Res., 52: 497-502.

Paris, H. S. (1996). Summer squash: history, diversity, and distribution, Hort. Technology, 6: 6-13.

Piper, C. S. (1947). Soil and Plant Analysis. The University of Adelaide (Australia) pp: 59-74.

Powell, W., C. Morgante, M. Hanafey, J. Vogel, S. Tingey and L. A. Rafa (1996). The comparison of RFLP, RAPD, AFLP and SSR (microsatellite) markers for germplasm analysis. Mol., Breed., 2: 225-238.

Prevost, A. and M. J. Wilkinson (1999). A new system of comparing PCR primers applied to ISSR fingerprinting of potato cultivars. Theor. Appl. Genet., 1: 107-112.

Rani, K. R. (2014). Performance of bitter gourd genotypes for yield and earliness. Annals of Plant and Soil Research, 16(4): 330-333.
Robertson, A. (1959). Experimental design in the evaluation of genetic parameters. Biometrics, 15: 219-226.

Salama, A. R., W. A. Fekry and H. M. Wahdan (2019). Influence of some squash cultivars and growth stimulants on flowering, yield and fruit quality at autumn- winter season under open field conditions. J. Prod. and Dev., 24(3): 433-460.

Sensoy, S., S. Buyukalaca and K. Abak (2007). Evaluation of genetic diversity in Turkish melons (Cucumis melo L.) based on phenotypic characters and RAPD markers. Genetic Resources Crop Evolution., 54(6): 1351-1365.

Shamloul, G. M. (2002). Evaluated of selected inbred lines of sweet melon (Ismailawy) and hybrids among them. Ph.D. Thesis, Fac. of Agric., Mansoura Univ., Egypt.

Silva, F. A. S. and C. A. V. Azevedo (2016a). Comparison of means of agricultural experimentation data through different tests using the software ASSISTAT. Afr. J. Agric. Res., 11(37): 3527-3531.

Silva, F. A. S. and C. A. V. Azevedo (2016b). The ASSISTAT software Version 7.7 and its use in the analysis of experimental data. Afr. J. Agric. Res., Vol. 11(39): 3733-3740.

Singh, R. K. and B. D. Chaudhary (1985). Biometrical methods in quantitative genetic analysis. Kalyani Publishers, New Delhi, India. 304 pp.

Someh, M., G. Kiani, G. A. Ranjbar and S. M. Alavi (2016). Assessment of genetic diversity in cucumber varieties using RAPD markers. J. Appl. Hort., 18(1):64-67.

Stansfield, W. D. (1983). Schaum's Outline of Theory and Problems of Genetics. McGraw-Hill. Inc. USA Stelling, D. and E. Ebmeyer (1990). Selection in early generations of dried peas (Pisum sativum L.). I. values of heritability and efficiency of indirect selection. Plant Breeding, 105(3): 169-179.

Tamil, N. A., P. Jansirani, L. Pugalendhi and A. Nirmalakumari (2012). Per se performance of genotypes and correlation analysis in pumpkin (Cucurbita moschata Duch. Ex Poir). Electronic Journal of Plant Breeding, 3(4): 987- 994.

Valdés-Restrepo, M. P., S. Ortiz-Grisales, F. A. VallejoCabrera and D. Baena-Garcia. (2013). Phenotypic stability of traits associated with fruit quality in butternut squash (Cucurbita moschata Duch.). Agron. Colombi., 31(2): 147-152.

Wilson, H. D. (1989). Discordant patterns of allozyme and morphological variation in Mexican Cucurbita. Systematic Botany, 14: 612-623.

Xanthopoulou, A., I. Ganopoulos, A. Kalivas, I. Nianiou-Obeidat and P. Ralli (2015). Comparative analysis of genetic diversity in Greek gene bank collection of summer squash (Cucurbita pepo) landraces using start codon targeted (SCoT) polymorphism and ISSR markers. Aust. J. Crop Sci., 9(1): 14-21. 
Xiao, J., L. J. Yuan, S. Mccouch and S. D. Tanksley (1996). Genetic diversity and its relationship to hybrid performance and heterosis in rice as revealed by PCR- based markers. Theor. Appl. Genet. 92: 637-643.

Xiong, F. Q., R. C. Zhong, Z. Q. Han, J. Jiang, L. Q. He, W. J. Zhuang and R. H. Tang (2011). Start codon targeted polymorphism for evaluation of functional genetic variation and relationships in cultivated peanut (Arachis hypogaea L.) genotypes. Mol.Biol. Rep., 38: 3487-3494.
Yildiz, M., E. Ekbic, D. Keles, S. Sensoy and K. Abak (2011). Use of ISSR, SRAP, and RAPD markers to assess genetic diversity in Turkish melons. Sci. Hort., 130: 349-353.

Yildiz, M., N. Akgul and S. Sensoy (2014). Morphological and molecular mharacterization of Turkish landraces of Cucumis melo L. Not. Bot.Horti.Agrobo., 42(1): 51-58.

Zietkiewicz, E. A., L. Rafalski and M. Dlubuda (1994). Genome fingerprinting by simple sequence repeat (SSR) anchored polymerase chain reaction amplification. Genome, 20: 176-178.

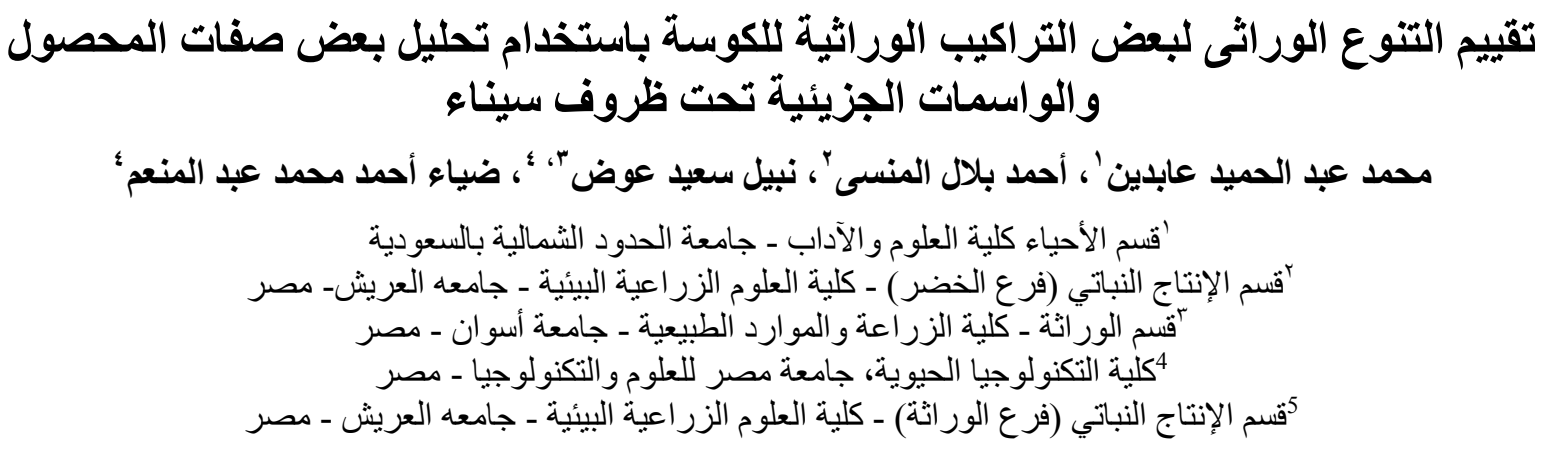

لدر اسة تقييم التتوع الور اثي لبعض التر اكيب الور اثنية في الكوسة تحت ظروف سيناء ـ مصر، تم إجراء تجربتين حقليتين لدر اسة

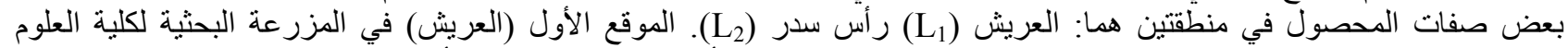

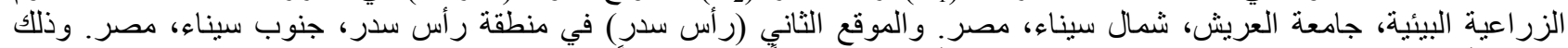

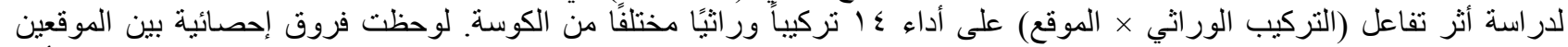

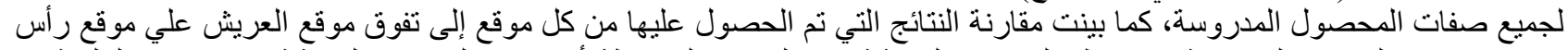

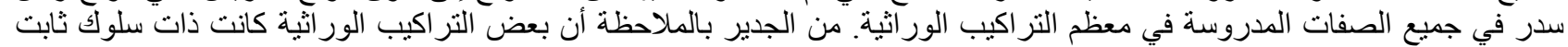

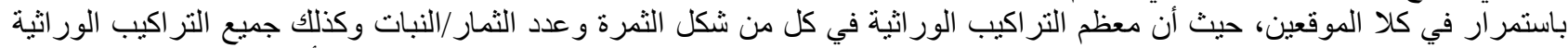

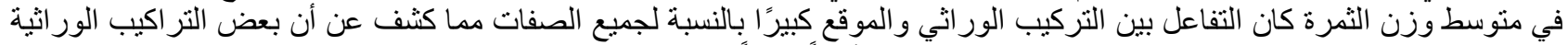

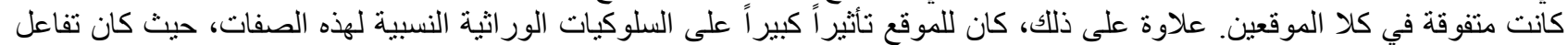

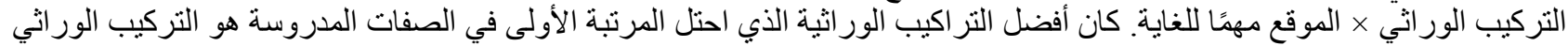

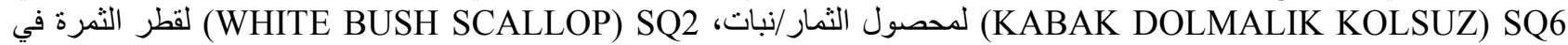
كلا الموقعين، كذلك SUITE BUSH SCALLOP) SQ2 و (ERBIL GARDEN) SQ7) لشكل الثمرة وكذلك

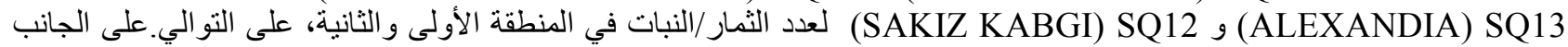

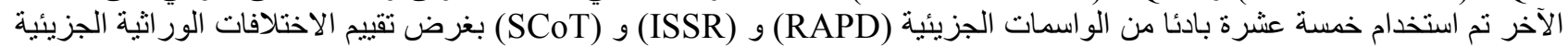

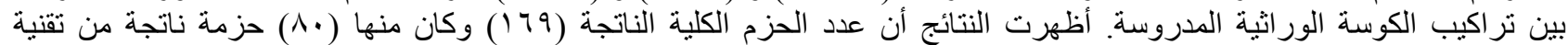

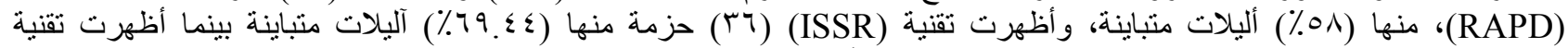

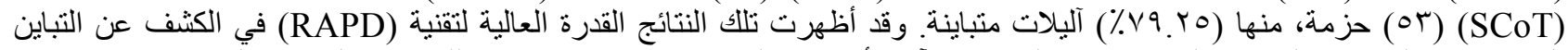

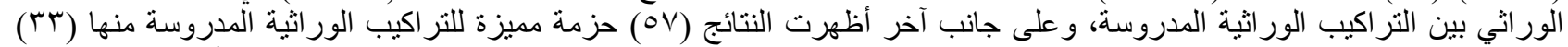

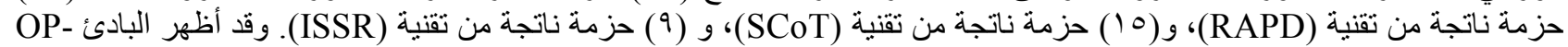

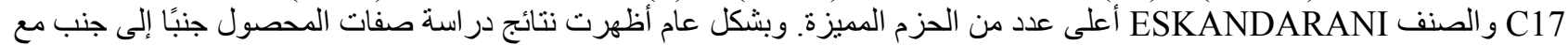

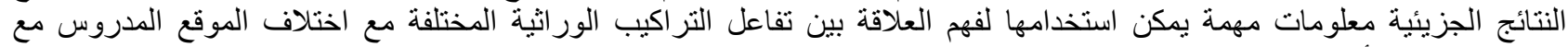
التوصية بزر اعة أفضل التر اكيب الور اثية في الموقع المناسب. 